\title{
Occurrence of myxosporean parasites in the gills of two tilapia species from Lake Nokoué (Bénin, West Africa): effect of host size and sex, and seasonal patterns of infection
}

\author{
A. Gbankoto ${ }^{1}$, C. Pampoulie ${ }^{2, *}$, A. Marques ${ }^{3}$, G. N. Sakiti ${ }^{1}$ \\ ${ }^{1}$ Faculté des Sciences et Techniques, Université Nationale du Bénin, BP 526 Cotonou, Bénin \\ ${ }^{2}$ KU Leuven, Laboratory of Aquatic Ecology, Ch. de Bériotstraat 32, 3000 Leuven, Belgium \\ ${ }^{3}$ Dép. B.E.E. cc96 Université Montpellier II, 34095 Montpellier cedex 05, France
}

\begin{abstract}
The gill myxosporean parasites of 2 euryhaline tilapias from Lake Nokoué, Sarotherodon melanotheron melanotheron (Rüppel, 1853) and Tilapia zillii (Gervais, 1852), were investigated from October 1987 to October 1989. A total of 391 S. m. melanotheron and 222 T. zillii were examined. Both of the fish species studied were infected by 3 host-specific myxosporean parasites for which prevalence greatly varied during our investigations. The 2 most common ones were Myxobolus sp. and $M$. zillii, which were located in the branchial filament. No significant fish sex effect was found for these 6 different myxosporean parasites. As seasonal pattern was clearly demonstrated for $M$. zillii while a host size effect was found for $M$. dossoui. However, further investigations of these myxosporean infections are necessary to determine the real effect of these parasites on their host, as host fecundity and survival was not assessed.
\end{abstract}

KEY WORDS: Tilapia $\cdot$ Myxobolus sp. $\cdot$ M. zillii $\cdot$ M. sarotherodoni $\cdot$ M. dossoui $\cdot$ M. beninensis . M. microcapsularis · Occurrence $\cdot$ Lake Nokoué

Resale or republication not permitted without written consent of the publisher

\section{INTRODUCTION}

Myxosporeans cause several kinds of damage and recent studies have highlighted their impact on the ovaries of their host (Gbankoto et al. 1999, Swearer \& Robertson 1999), suggesting that reproduction in infected females could be affected. In West Africa, fish farms are said to offer a solution to the problem of low fish catches in countries such as Bénin (Morissens et al. 1986) and Côte d'Ivoire (Doudet 1991). In these regions, tilapia species could offer a real potential for fish farms and for the local economy (Stickney 1986). Tilapia farms in West Africa should be located in lagoons and estuaries (Payne 1983) where salinity may

\footnotetext{
*Corresponding author. E-mail: pampoulie@univ-montp2.fr
}

vary from 0 to $90 \mathrm{~g} \mathrm{l}^{-1}$ (Alabaret 1987); it is necessary, therefore, to rear fishes resistant to variations in salinity (Doudet 1992, Lahav \& Ra'anan 1997) that affect osmoregulation (Bone \& Marshall 1982). Constant changes in salinity involve energetic costs (Bone \& Marshall 1982) that render tilapia more susceptible to parasites. In light of the fact that gills are the most important regulator of osmoregulation in fishes (Maetz \& Bornancin 1975, Foskett et al. 1981, Li et al. 1995) and that myxosporean parasites occur on fish gills, decreasing the respiratory capacity of the fish (McCraren et al. 1975, Molnár \& Székely 1999), we decided to study myxosporean diseases in 2 tilapia species, Sarotherodon melanotheron melanotheron (Rüppel, 1853) and Tilapia zillii (Gervais, 1852), which are 2 important species in tilapia aquaculture (Pauly 1976, Legendre 1983) known to be affected by myxosporean parasites 
of the gills (Fomena 1986, Sakiti et al. 1991). The aim of this study was to investigate the occurrence of myxosporean parasites that affected these 2 species in Lake Nokoué (Bénin, West Africa) and the principal factors (seasonality and length of fish) that influenced their occurrence.

\section{MATERIALS AND METHODS}

Environment. Samples were collected from October 1987 to October 1989 in Lake Nokoué (Fig. 1). The maximum area of this lake was $160 \mathrm{~km}^{2}$. The weather here was characterised by 2 dry seasons and 2 wet seasons. The sampling months were grouped per season that were designated S1 (long dry season from December to March), S2 (long wet season from April to July), S3 (short dry season from August to September) and S4 (short wet season from October to November). Thus, the long wet season of 1988 was designated S2-88.

Mean water temperature varied from 25.6 to $31.5^{\circ} \mathrm{C}$ (Fig. 2) while salinity greatly varied during the year (Fig. 2), with a minimum of $0.02 \mathrm{~g} \mathrm{l}^{-1}$ and a maximum of $29.77 \mathrm{~g} \mathrm{l}^{-1}$. Salinity increased with the arrival of marine water through the Cotonou channel and decreased during the wet season. Precipitation was usually high from May to August (Fig. 2).

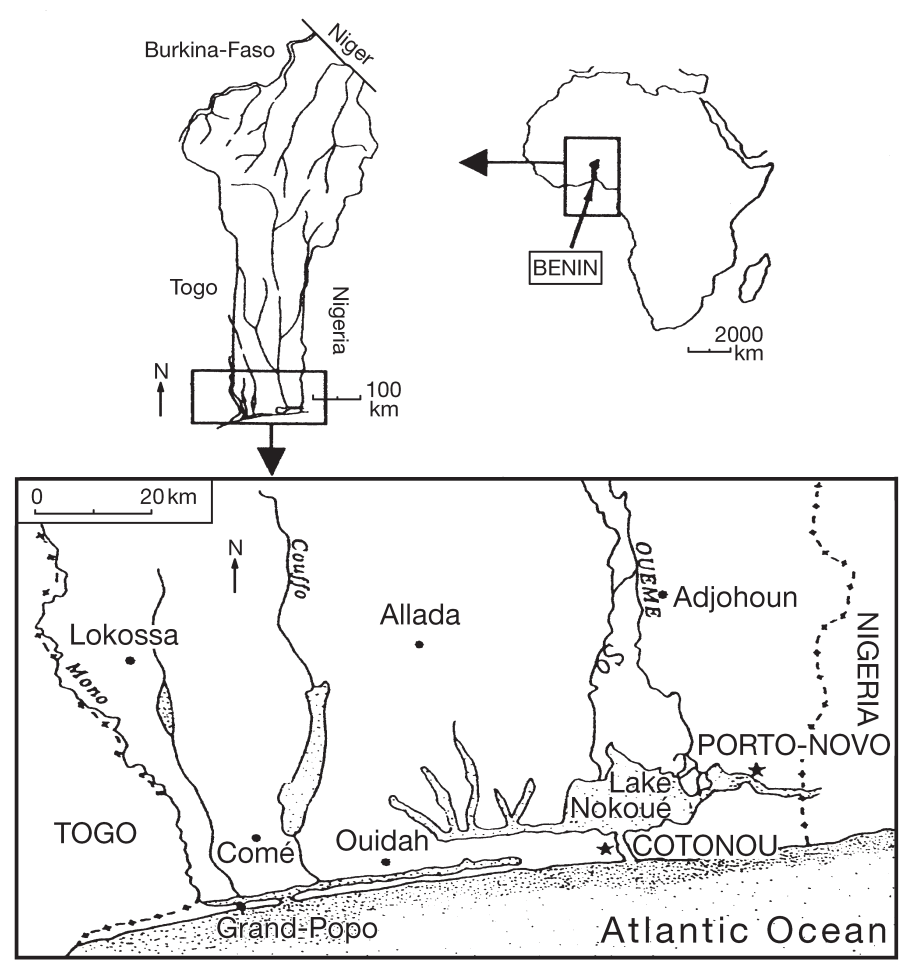

Fig. 1. Sampling sites in Lake Nokoué (Bénin, West Africa)

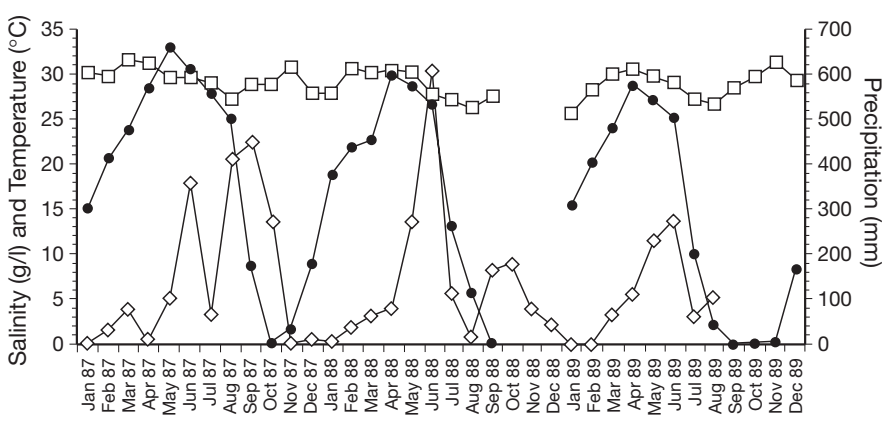

Fig. 2. Seasonal changes in the salinity $(\bullet)$, temperature ( $\square$ ) and precipitation $(\diamond)$ of Lake Nokoué (Bénin, West Africa)

Data collection. A total of 391 Sarotherodon melanotheron melanotheron (Rüppel, 1853) and 222 Tilapia zillii (Gervais, 1852) individuals were examined. Fish were brought alive to the laboratory for species and sex determination. The total length (mm) and the weight (mg) were measured. Size frequency distributions were done for both species. Each month, approximately 30 fishes of both species were investigated for parasite infection and determination. Parasites were detected by the presence of white cysts on the gills under the stereomicroscope and by observation of these cysts in vivo in phase contrast. Prevalence was calculated as the ratio of the number of individuals containing at least 1 visible white cyst to the total number of fish examined. The effect of fish size, sex and season on prevalence was tested using the $\chi^{2}$ test.

\section{RESULTS}

\section{Population structure of hosts}

Fish were placed in different size groups (50 to 100 , 100 to 150,150 to 200 and 200 to $250 \mathrm{~mm}$ ). In Sarotherodon melanotheron melanotheron, $1.28 \%$ of the individuals ranged between 50 and $100 \mathrm{~mm}, 53.45 \%$ between 100 and $150 \mathrm{~mm}, 43.74 \%$ between 150 and $200 \mathrm{~mm}$ and $1.53 \%$ between 200 and $250 \mathrm{~mm}$. In Tilapia zillii, individuals were distributed as follows: $5.41 \%$ in the class 50 to $100 \mathrm{~mm}, 68.47 \%$ in the class 100 to $150 \mathrm{~mm}, 25.22 \%$ in the class 150 to $200 \mathrm{~mm}$ and $0.90 \%$ in the class 200 to $250 \mathrm{~mm}$. A total of 119 male and 103 female T. zillii were caught while 271 male and 113 female $S$. m. melanotheron were caught.

\section{Seasonal patterns of prevalence}

Myxobolus sp. and $M$. zillii are respectively parasites of the branchial filament of Sarotherodon melano- 
theron melanotheron and Tilapia zillii. The prevalence of these 2 parasites was $20.20 \%$ (79 affected fishes out of 391 examined) and $14.86 \%$ (33 affected fishes out of 222 examined) respectively. Myxobolus sp. was found in $S . m$. melanotheron throughout our study except during S4-87 (Fig. 3a) and its occurrence varied significantly from one season to another $\left(\chi^{2}\right.$ test, $\chi^{2}=96.86$, $\mathrm{df}=8, \mathrm{p}<0.001$ ). The prevalence of $M$. zillii (Fig. 3a) found in $T$. zillii varied significantly from 0 (S4-87, S3-88) to $30.77 \%$ (S4-89) $\left(\chi^{2}\right.$ test, $\chi^{2}=17.28, \mathrm{df}=8$, $\mathrm{p}<0.05)$.

Myxobolus sarotherodoni and M. dossoui are parasites of the branchial arch cartilage of Sarotherodon melanotheron melanotheron and Tilapia zillii respectively. The prevalence of these 2 parasites was $4.86 \%$ (19 affected fishes out of 391 examined) and 13.51\% (30 affected fishes out of 222 examined) respectively. M. sarotherodoni (Fig. 3b) was found in S. m. melanotheron in (S1-88) to the end of our study, and its occurrence did not vary significantly from one season

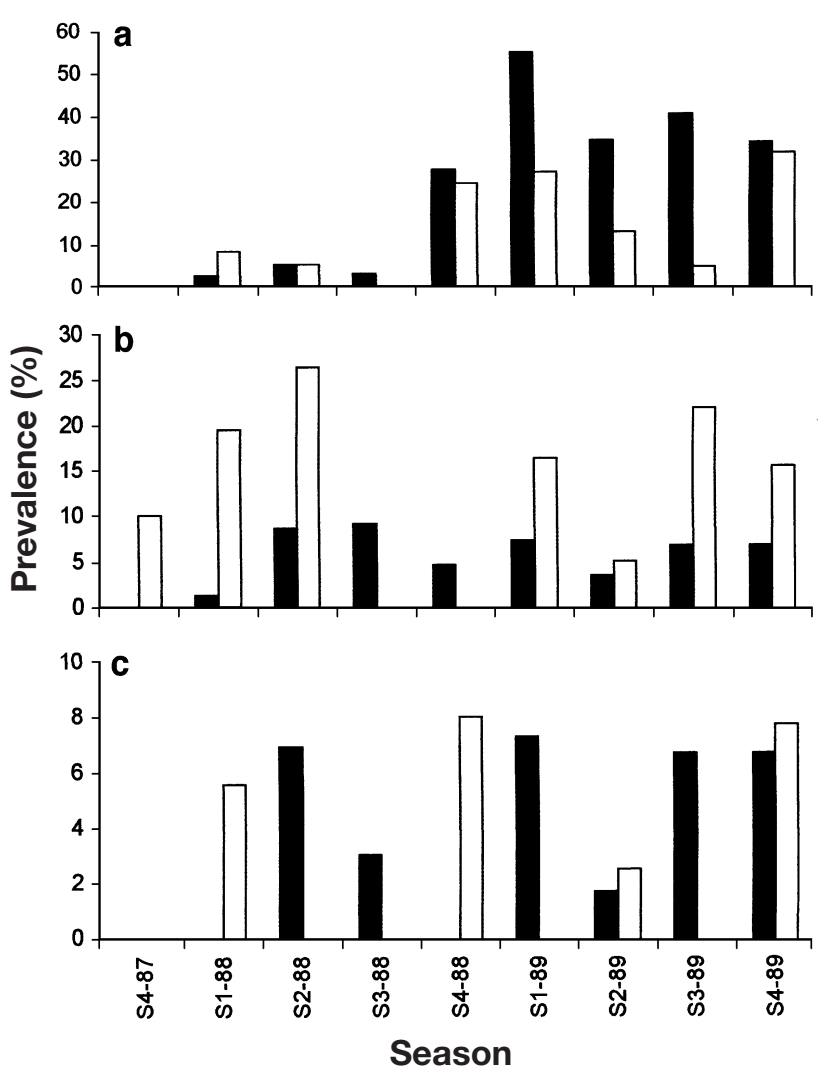

Fig. 3. Prevalence of myxosporean parasites in Sarotherodon melanotheron melanotheron and Tilapia zillii in Lake Nokoué (Bénin, West Africa). Myxosporean parasites of the (a) branchial filament: Myxobolus sp. (filled bars), M. zillii (open bars); (b) branchial arch cartilage: $M$. sarotherodoni (filled bars); $M$. dossoui (open bars); (c) branchial arch: $M$. beninensis (filled bars); M. microcapsularis (open bars). Sampling season and year given on $x$-axis to another ( $\chi^{2}$ test, $\chi^{2}=8.60, \mathrm{df}=8, \mathrm{~ns}$ : non significant). The prevalence of $M$. dossoui (Fig. 3b) found in T. zillii did not vary significantly $\left(\chi^{2}\right.$ test, $\chi^{2}=0.62$, df $\left.=8, \mathrm{~ns}\right)$.

Myxobolus beninensis and $M$. microcapsularis are parasites of the branchial arch of Sarotherodon melanotheron melanotheron and Tilapia zillii respectively. The prevalence of these 2 parasites was $3.32 \%$ (13 affected fishes out of 391 examined) and $2.70 \%$ (6 affected fishes out of 222 examined) respectively. $M$. beninensis (Fig. 3c) was found in S. m. melanotheron throughout the study except during S4-87, and S4-88. Its occurrence did not vary significantly form one season to another $\left(\chi^{2}\right.$ test, $\left.\chi^{2}=11.88, \mathrm{df}=8, \mathrm{~ns}\right)$. The prevalence of $M$. microcapsularis (Fig. 3c) found in T. zillii did not vary significantly $\left(\chi^{2}\right.$ test, $\chi^{2}=8.02$, df $=8$, ns $)$.

\section{Prevalence within host size}

In Sarotherodon melanotheron melanotheron, prevalence of Myxobolus sp. did not vary significantly $\left(\chi^{2}\right.$ test, $\left.\chi^{2}=0.51, \mathrm{df}=3, \mathrm{~ns}\right)$ with respect to fish size (Fig. 4a) or prevalence of $M$. sarotherodoni $\left(\chi^{2}\right.$ test, $\chi^{2}=$ 1.96, $\mathrm{df}=3$, ns) (Fig. $4 \mathrm{~b}$ ) or $M$. beninensis $\left(\chi^{2}\right.$ test, $\chi^{2}=$ 1.05, df $=3$, ns) (Fig. 4c). In Tilapia zillii, prevalence of M. zillii ( $\chi^{2}$ test, $\chi^{2}=3.34$, df $=3$, ns) did not vary significantly with respect to fish size (Fig. 4a) or prevalence of $M$. dossoui ( $\chi^{2}$ test, $\chi^{2}=13.47$, df $=3$, ns) (Fig. 4b) or M. microcapsularis $\left(\chi^{2}\right.$ test, $\chi^{2}=0.97, \mathrm{df}=3$, ns) (Fig. 4c).

\section{Prevalence by sex}

Prevalence of Myxobolus sp. in male (20.66\%, 56 affected fishes out of 271 examined) and female (20.35\%, 23 affected fishes out of 113 examined) Sarotherodon melanotheron melanotheron did not differ significantly ( $\chi^{2}$ test, $\left.\chi^{2}=0.004, \mathrm{df}=1, \mathrm{~ns}\right)$, nor did prevalence of $M$. zillii in male $(13.44 \%, 16$ affected fishes out of 119 examined) or female $(16.50 \%, 17$ affected fishes out of 103 examined) Tilapia zillii ( $\chi^{2}$ test, $\left.\chi^{2}=0.41, \mathrm{df}=1, \mathrm{~ns}\right)$.

Prevalence of Myxobolus sarotherodoni in male (5.53\%, 15 affected fishes out of 271 examined) and female $(3.54 \%, 3$ affected fishes out of 113 examined) Sarotherodon melanotheron melanotheron did not differ significantly ( $\chi^{2}$ test, $\left.\chi^{2}=0.68, \mathrm{df}=1, \mathrm{~ns}\right)$, nor did the prevalence of $M$. dossoui in male $(11.76 \%, 14$ affected fishes out of 119 examined) or female $(15.53 \%, 16$ affected fishes out of 103 examined) Tilapia zillii ( $\chi^{2}$ test, $\left.\chi^{2}=0.62, \mathrm{df}=1, \mathrm{~ns}\right)$.

Prevalence of Myxobolus beninensis in male (4.06\%, 2 affected fishes out of 271 examined) and female (1.77\%, 2 affected fishes out of 113 examined) Sarotherodon melanotheron did not differ significantly 

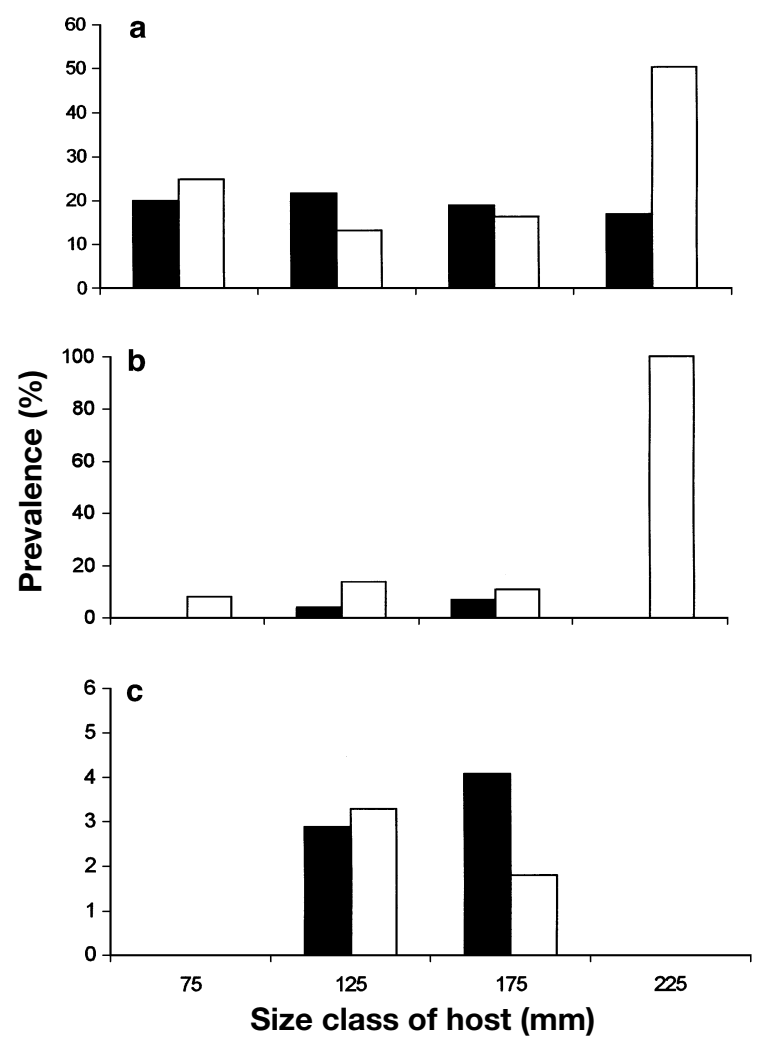

Fig. 4. Prevalence of myxosporean parasites in relation with the size of their hosts Sarotherodon melanotheron melanotheron and Tilapia zillii in Lake Nokoué (Bénin, West Africa). Myxosporean parasites of the (a) branchial filament: Myxobolus sp. (filled bars), M. zillii (open bars); (b) branchial arch cartilage: $M$. sarotherodoni (filled bars), $M$. dossoui (open bars); (c) branchial arch: $M$. beninensis (filled bars), M. microcapsularis (open bars)

( $\chi^{2}$ test, $\chi^{2}=3.84, \mathrm{df}=1, \mathrm{~ns}$ ), nor did the prevalence of M. microcapsularis in male $(3.36 \%, 4$ affected fishes out of 119 examined) or female Tilapia zillii $(1.94 \%, 2$ affected fishes out of 103 examined) differ significantly $\left(\chi^{2}\right.$ test, $\left.\chi^{2}=0.42, \mathrm{df}=1, \mathrm{~ns}\right)$.

\section{DISCUSSION}

\section{Prevalence data}

Our results clearly showed that the prevalence of the different myxosporean parasites that infected Sarotherodon melanotheron melanotheron and Tilapia zillii was high and greatly varied. The most common parasites were Myxobolus sp. (20.20\%) found in S. $m$. melanotheron, M. zillii (14.86\%) in T. zillii, which are both located in branchial filaments, and $M$. dossoui $(13.51 \%)$, which is located in the branchial arch cartilage. The prevalence of Myxobolus sp. in S. m. melanotheron was higher than that found in the gills of
Labeo niloticus (between 12 and $20 \%$ for different Myxobolus sp.) or Clarias lazera (14\% for Henneguya branchialis) (Ghaffar et al. 1995) but lower than that found in the gills of Abramis brama (Molnár \& Székely 1999). In contrast, the prevalence of $M$. zillii and $M$. dossoui was close to that which was observed in the gills of C. lazera (Ghaffar et al. 1995). The other parasite species studied were found only sporadically ( 2 to $4 \%$ ), as are parasite species usually observed on freshwater fishes (Ghaffar et al. 1995, Molnár \& Székely 1999). Myxosporean parasites on gills are known to induce mortality such as Henneguya sp. in catfishes (McCraren et al. 1975), distorsion in branchials lamellae such as $H$. chrysichthyi in Chrysichthys nigrodigitatus (Obiekezie \& Enyenihi 1988) and liquefaction of cartilaginous tissues of gills such as $M$. cartilaginis in Lepomis macrochirus (Hoffman et al. 1965). These diseases which cause a reduction in the respiratory capacity of fish pose a threat to the fish and thus to the farms. The high prevalence of myxosporea and their presence on tilapia gills suggested that further studies on the potential effect of these parasites on their hosts are needed, as myxosporea probably causes a reduction in the respiratory capacity of the fish and negatively affect their fitness.

\section{Parasites and sex of host}

Males are known to be usually more sensitive to parasites than females due to testosterone synthesis which may exert a cost, decreasing immune competency. In our study, prevalence did not vary significantly with the sex of the host, showing that males were not more sensitive than females to these parasites and revealing that this sex difference could be irrelevant (Poulin 1996).

\section{Parasites and age of fish}

When parasites do not induce host mortality, the continued acquisition of parasites through time tends to increase the parasite load in the older age classes of the host. Thus, the highest prevalence was observed in larger fish (Lester 1984). In myxosporean parasites, Gonzalez-Lanza \& Alvarez-Pellitero (1985) have already mentioned the effect of host size and sex on the prevalence of Myxobolus pseudodispar, M. leuciscini and $M$. ellipsoides. Mitchell (1989) highlighted the fact that the prevalence of $M$. muelleri and M. dujardini, parasites of Psychocheilus oregonensis, P. caurinus and Richardsonius blateatus, was higher in the oldest fish, suggesting that host death is independent of parasite load. During our study, the prevalence of M. dossoui was the only one that differed significantly within 
host sizes. This species is located in the cartilaginous tissues of the branchial arch, i.e. it is not in contact with the external environment except during host death or the destruction of the branchial arch. Therefore, in order to release its infective forms into the environment, this parasite needs to wait for the death of its host or to induce it. Parasites which are not in contact with the environment have already been considered to be parasites which induce host death (Pampoulie et al. $1999,2000)$. Thus, the low prevalence of $M$. dossoui in the large size class of fish was probably due to a die-off of the highly infected fishes.

Prevalence of Myxobolus zillii and M. dossoui did not vary significantly within host size but peaks were observed in the larger size class, suggesting an increase in parasite load with fish age. These results should be viewed with caution, as only a few individuals ( 1 to $2 \%$ ) in this size class were caught.

\section{Seasonal variations in parasitosis}

The seasonal pattern of prevalence did not vary significantly except for species affecting the branchial filaments, e.g. Myxobolus sp. and M. zillii. In these particular environments, we believe that the seasonal pattern of these 2 myxosporea cannot be explained directly by temperature variations, which has been shown to be the case for Sphaerospora renicola in common carp (Grupcheva et al. 1985) and for different species of the genus Ceratomyxa (Alvarez-Pellitero \& Sitja-Bobadilla 1993). On the contrary, the combination of fluctuations in salinity, temperature and $\mathrm{pH}$ between dry and wet seasons probably affects the parasite cycle by causing modifications in host behaviour (migration to avoid decreases in salinity or changes in the environment) and/or by rendering the host more sensitive to the parasite by increasing the osmoregulatory cost. Thus, the associated changes in these parameters probably affect the parasite cycle by modifying the contact zone between parasites and their hosts. The parasite cycle may also be synchronised with the host cycle (Pampoulie et al. 2000), inducing a modification of prevalence in relation with the life cycle of host.

Acknowledgements. Particular thanks are addressed to the members of the direction of fisheries and to the ASECNA of Cotonou for their help during the sampling and the collection of data on the physico-chemical parameters of the environment.

\section{LITERATURE CITED}

Alabaret JJ (1987) Les peuplements de poissons de la Casamance (Sénégal) en période de sécheresse. Rev Hydrobiol Trop 20:291-310
Alvarez-Pellitero P, Sitja-Bobadilla A (1993) Population dynamic of Ceratomyxa spp. (Protozoa: Myxosporea) infection in wild and cultured sea bass, Dicentrarchus labrax (L) from the Spanish Mediterranean area. J Fish Biol 42: 889-901

Bone Q, Marshall NB (1982) Osmoregulation and ion balance. In: Bone Q, Marshall NB (eds) Biology of fishes. Chapman \& Hall, New York, p 107-129

Doudet T (1991) Recherche sur l'aquaculture des tilapias en milieu lagunaire. Report of CTFT-CIRAD, Nogent-surMarne

Doudet T (1992) Brackishwater tolerance of some species and hybrids of Oreochromis for use in lagoon aquaculture (Côte d'Ivoire). Aquaculture 102:275-288

Fomena A (1986) Contribution à l'étude des Myxosporidies (Protozoa: Myxozoa) parasites des poissons d'eau douce du sud-Cameroun: systématique, ultrastructure, relations hôte-parasite. $\mathrm{PhD}$ thesis, Université Yaoundé, Cameroun

Foskett JK, Logsdon CD, Turner T, Machen TE, Bern NA (1981) Differentiation of the chloride extrusion mechanism during sea water adaptation of a teleost fish, the cichlid Sarotherodon mossambicus. J Exp Biol 93:209-224

Gbankoto A, Sakiti N, Marques A (1999) Occurrence of a pathology linked to Myxobolus dahomeyensis (SIAU, 1971) a Myxosporean parasite of wild and cultured tilapia ovaries in Benin. J Eukaryot Microbiol 46:14A

Ghaffar FA, El-Shahawi G, Naas S (1995) Myxosporidia infecting some Nile fishes in Egypt. Parasitol Res 81: 163-166

Gonzalez-Lanza MC, Alvarez-Pellitero P (1985) Myxobolus spp. of various cyprinids from the river Elsa (Leon, NW Spain). Description and population dynamics. Angew Parasitol 26:71-83

Grupcheva G, Dykova I, Lom J (1985) Seasonal fluctuation in prevalence of Sphaerospora renicola and Myxosporean blood stages in Carp fingerlings in Bulgaria. Folia Parasitol 32:193-203

Hoffman GL, Putz RE, Dnbar CE (1965) Studies on Myxosoma cartilaginis n. sp. (Protozoa: Myxosporidea) of centrarchid fish and a synopsis of the Myxosoma of North American freshwater fishes. J Protozool 12:319-332

Lahav E, Ra'anan Z (1997) Salinity tolerance of genetically produced tilapia (Oreochromis) hybrids. Isr J Aquacult Bamidgeh 49:160-165

Legendre M (1983) Observations préliminaires sur la croissance et le comportement en élevage de $S$. melanotheron (Rüppel 1853) et de Tilapia guineensis (Bleeker, 1862) en lagune Ebrié (Côte d'Ivoire). Doc Sci Cent Rech Océanogr Abidjan ORSTOM 14:1-36

Lester RJG (1984) A review of methods for estimating mortality due to parasites in wild fish populations. Helgol Meeresunters 37:53-64

Li J, Egendteyn J, Lock RAC, Verbost PM, Van Der Heijden AJH, Wendelaar Bonga SE, Flik G (1995) Branchial chloride cells in larvae and juveniles of freshwater tilapia Oreochromis mossambicus. J Exp Biol 198:2177-2184

Maetz J, Bornancin M (1975) Biochemical and biophysical aspects of salt excretion by chloride in teleosts. Fortschr Zool 22:322-362

McCraren JP, Hoffman GL, Meyer FP (1975) Variation in response of channel catfish to Henneguya sp. infections (Protozoa: Myxosporidea). J Wildl Dis 11:2-7

Mitchell GL (1989) Myxobolid parasites (Myxozoa: Myxobolidae) infecting fishes of Western Montana, with notes on histopathology, seasonality, and intraspecific variation. Can J Zool 67:1915-1922

Molnár K, Székely C (1999) Myxobolus infection of the gills of 
common bream (Abramis brama L.) in lake Balaton and in the Kis-Balaton reservoir, Hungary. Acta Vet Hung 47: 419-432

Morissens P, Roche P, Aglinglo C (1986) La pisciculture intensive en enclos dans les grandes lagunes du sud-est Bénin. Bois For Trop 213:51-70

Obiekezie AL, Enyenihi UK (1988) Henneguya chrysichthyi sp. nov. (Protozoa: Myxozoa) from the gills of estuarine Catfish Chrysichthys nigrodigitatus (Lacepede) (Pisces: Bagridea) in Nigeria. Rev Zool Afr 102:33-42

Pampoulie C, Morand S, Lambert A, Rosecchi E, Bouchereau JL, Crivelli AJ (1999) Influence of the Trematode Aphalloïdes cœlomicola Dollfus, Chabaud \& Golvan, 1957 on the fecundity and survival of Pomatoschistus microps (Krøyer, 1838) (Teleostei, Gobiidæ). Parasitol 119:61-68

Pampoulie C, Lambert A, Rosecchi E, Crivelli AJ, Bouchereau JL, Morand S (2000) Host death: a necessary condition for the transmission of Aphalloides cœlomicola Dollfus, Chabaud \& Golvan, 1957. J Parasitol 86:416-417

Editorial responsibility: Wolfgang Körting, Hannover, Germany
Pauly D (1976) The biology, fishery and potential for aquaculture of Tilapia melanotheron in a small West African lagoon. Aquaculture 7:33-47

Payne AI (1983) Estuarine and salt tolerant tilapias. In: Fishelson L, Yaron Comps Z (eds) Proceedings of the International Symposium on Tilapia in Aquaculture. Tel-Aviv University, Tel Aviv, p 534-543

Poulin R (1996) Sexual inequalities in Helminth infections: a cost of being a male? Am Nat 147:287-295

Sakiti GN, Blanc E, Marques A, Bouix G (1991) Myxosporidies (Myxozoa, Myxosporea) du genre Myxobolus Bütschli, 1882 parasite de Poissons Cichlidae du lac Nokoué au Bénin (Afrique de l'Ouest). J Afr Zool 105:173-186

Stickney RR (1986) Tilapia tolerance to saline waters: a review. Prog Fish Cult 48:161-167

Swearer SE, Robertson DR (1999) Life history, pathology, and description of Kudoa ovivora n. sp. (Myxozoa, Myxosporea): an ovarian parasite of Caribbean labroid fishes. J Parasitol 85:337-353

Submitted: May 29, 2000; Accepted: December 20, 2000 Proofs received from author(s): March 19, 2001 